\title{
Hezegune eraikiak ur grisen tratamendurako
}

\section{(Constructed wetlands for greywater treatment)}

\author{
Onintze Parra ${ }^{1,2}$, Federico Mijangos ${ }^{1}$, Roberto Aguado ${ }^{* 1,2}$ \\ ${ }^{1}$ Ingeniaritza Kimikoa Saila, UPV/EHU \\ ${ }^{2}$ Euskal Herriko Mugarik Gabeko Ingeniaritza
}

\begin{abstract}
LABURPENA: Hezegune eraikiak ur grisen tratamendurako sistema merkeak, instalatzeko errazak eta jasangarriak dira, ohiko kutsatzaileak eliminatzeko gaitasun handia dutelako. Gainazaleko eta gainazal azpiko fluxuko erakoak dira hezegune eraiki mota nagusiak, azkenak hondakin uren tratamendurako eraginkorragoak izanik. Bakoitzaren hoberena aprobetxatzeko, gero eta erabiliagoak dira bi hezegune motak konbinatzen dituzten sistema hibridoak. Hondakin-uren arazketa ona izan dadin, ezinbestekoa da diseinu-parametroen aukeraketa egokia, eta funtsezkoa da landarediaren hautaketa. Izan ere, hezegune eraikian elikatzen diren ur grisek materia organiko eta mantenugai ugari daramatzate, eta landareak eta mikroorganismoak izango dira kutsatzaile horien eliminazioaren arduradun. Karga organiko handia izateaz gain, hezegunean elikatzen diren hondakin-urek solido esekiak eta konposatu nitrogenatuak daramatzate. Hortaz, hezeguneek ohantze iragazleak izan ohi dituzte lehenengoak eliminatzeko, eta nitrifikazio- eta desnitrifikazio-prozesuak gauzatzen dituzte konposatu nitrogenatuak desagerrarazteko. Lan honetan, hezegune eraiki moten ezaugarriak eta horien abantailak zein desabantailak aztertu dira, bertan elikatzen diren uren karakterizazioa laburtu da, eta, azkenik, hezegune eraikietan urak arazteko gauzatzen diren prozesu fisiko, kimiko zein biologiko nagusiak bildu dira.
\end{abstract}

HITZ GAKOAK: hezegune eraikia, ur-arazketa, hondakin-urak, ur grisak.

ABSTRACT: Constructed wetlands are low cost, easy to install and sustainable grey-water treatment systems, due to their capacity for removing conventional pollutants. Constructed wetlands are classified as free water surface flow type and subsurface flow type, being the last one more effective for wastewater treatment. Hybrid systems that combine both types of wetlands are increasingly used to harness the best of each wetland type. In order to achieve a satisfactory wastewater purification, an adequate selection of the design parameters is essential, being a key point the adequate choice of plant species. Grey-water fed to the constructed wetland contains large amounts of organic matter and nutrients, being plants and microorganisms responsible for the elimination of these pollutants. Additionally wastewater carries suspended solids and nitrogen compounds. The formers are eliminated by filtration in the gravel bed, while the latter by nitrification and denitrification. In this work, the main characteristics of the constructed wetland types and their advantages and disadvantages have been commented, as well as the characterization of the entering wastewater and a summary of the main physical, chemical and biological processes that are carried out for the purification of water in constructed wetlands.

KEYWORDS: constructed wetland, wastewater treatment, wastewater, greywater.

* Harremanetan jartzeko / Corresponding author: Roberto Aguado. Ingeniaritza Kimikoa Saila, Zientzia eta Teknologia Fakultatea, UPV/EHU, Sarriena auzoa, z/g (48940 Leioa, Bizkaia). - roberto.aguado@ehu.eus - https://orcid.org/0000-0001-87435696

Nola aipatu / How to cite: Parra, Onintze; Mijangos, Federico; Aguado, Roberto (2021). «Hezegune eraikiak ur grisen tratamendurako". Ekaia, 41, 2021, 191-205. (https://doi.org/10.1387/ekaia.22773).

Jasotze-data: 2021, maiatzak 3; Onartze-data: 2021, uztailak 7.

ISSN 0214-9753 - elSSN 2444-3581 / (c) 2021 UPV/EHU

cc)()ㅇ Lan hau Creative Commons Aitortu-EzKomertziala-LanEratorririkGabe 4.0 Nazioartekoa

(izentzia baten mende dago 


\section{SARRERA}

Hondakin-uren tratamendua ezinbestekoa da gizakiaren ongizatea bermatzeko. Ez bakarrik saneamendu ezak dakartzan osasun- eta ingurumenarazoengatik, baita mundu mailan gero eta larriagoa bihurtzen ari den ur eskasiaren problematikagatik ere [1]. Populazioak gora egiten duen heinean, ureztatzeko eta nekazaritzarako ur eskaria ere handitzen doa. Horrekin batera, garapen industrialak eta egungo bizimoduak hondakin-uren bolumena eta kutsatzaileen kontzentrazioa handitzea ekarri dute, eta horiek klima-aldaketarekin batera, ur eskasia areagotu dute [2]. Horregatik, eta nahiz eta ura baliabide natural ugaria izan, ez da nahikoa izango etorkizuneko beharrak asetzeko [3], eta, hortaz, hondakin-uren tratamendua eta berrerabilpena funtsezko bihurtu da ur-eskaria betetzeko [1].

Hezegune eraikiak, hezegune artifizialak edota biojardinerak ere deituak, hondakin-uren tratamendurako arazketa-sistema naturalak dira. Ura arazteko naturaren prozedura errepikatuz, hezegune naturaletan gertatzen diren prozesu fisiko, kimiko eta biologikoetaz baliatzen dira uraren kutsadura murrizteko eta bere kalitatea hobetzeko [4]. Hain zuzen, mikroorganismoen eta landareen materia organikoa eliminatzeko ahalmena aprobetxatzen dute [5]. Sistema zentralizatuen aurrean, arazketa-sistema naturalak erakargarriak bihurtu dira [6] kanpoko energiarik eta gehigarri kimikorik behar ez dutelako [5], bai ekonomikoki bai ingurumenaren aldetik ere jasangarriak direlako, eta kutsatzaile arruntak eliminatzeko gaitasun handia dutelako.

Hezegune eraikiak 1952. urtean sortu ziren, Alemanian hain zuzen, landa-eremuetako etxeko ur grisak tratatzeko helburuarekin [6]. Urteetan zehar, arazketa-sistema horiek erabili dira jatorri askotariko hondakin-urak tratatzeko, baina etxeko eta hiriko urak izan dira elikadura nagusiak. Hala ere, industriatik datozen urak, meatze-erauzketan sortutako drainatze-urak zein lohien deshidratazioan eta mineralizazioan sortutakoak ere trata daitezke [7]. Dena den, etxeko hondakin-uren patogeno kutsatzaileak eta nitrogeno-kontzentrazioak urriak direnez, gaur egun, ikerketa-lan askoren jomugan dago ur grisen tratamendu eta berrerabilpenerako sistema naturalen ahalmena [8], eta hezegune eraikiak biziki gomendatzen dira ur grisen tratamendurako landa-eremuetan eta komunitate txikietan [7].

Arazketa sistema horietan hiru etapa nagusi lotzen dira: bilketa, tratamendua eta ingurura itzultzea [9]. Eraikuntzara begira, alde batetik, kontuan hartu behar da uraren fluxu naturala erraztu behar dela; hau da, ahal den heinean malda moderatuak aprobetxatu behar direla. Bestetik, lur azpiko uren osasuna eta kalitatea zaintzeko, urmaela hondeatu ostean mintz iragazgaitzarekin estali behar da legarrez osatu baino lehen [7]. Hidrofitoak landatu ostean, ur grisak elikatzen hasten dira, eta zenbait aste behar dira arazketa-ahalmen optimoa lortzeko. Elikatzen den uraren ezaugarrien 
eta ingurura bueltatzeko bete behar diren zehaztapenen arabera, tratamendu ezberdinak jasoko ditu emariak. Hezegune eraikiak sedimentazioz, mikroorganismoen bidezko degradazioz, absortzioz, erreakzio kimikoz eta lurrunketaz baliatzen dira arazketa-prozesua aurrera eramateko [7], ohiko tratamendu sekundarioak ordeztuz.

\section{HEZEGUNE ERAIKI MOTAK}

Hezegune eraikiak landarediaren, tratatutako hondakin uren edota fluxuaren konfigurazioaren arabera sailka daitezke; azkena da erabiliena. Horrela, hezegune eraikiak gainazaleko fluxukoak edo gainazal azpiko fluxukoak izan daitezke [10].

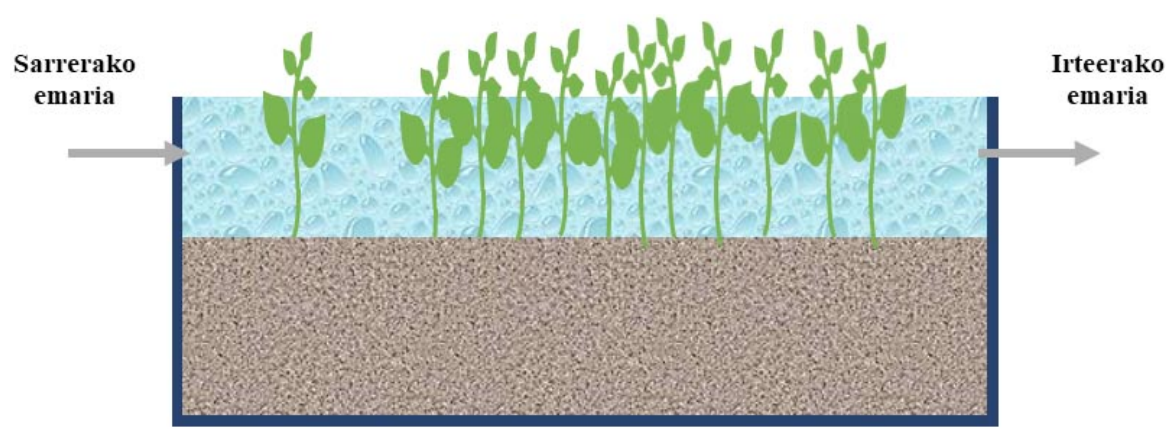

1.irudia. Gainazaleko fluxuko hezegune eraikiaren eskema.

Gainazaleko fluxuaren (GF) kasuan, 1. irudia, hondakin-urak hezegunearen gainazalean dabiltza, ohantzearen gainean. Mota hori gomendatzen da gainezkatzeak saihesteko [11] eta aurretik tratatutako uraren kalitatea hobetzeko [5]. Sistema horietan, ur-emaria landareen zurtoinen eta hostoen artean dabil eta atmosferarekin kontaktuan dago momentu oro. Hezegune naturalen antza handia dute, baina sakonera gutxiagorekin $(0,6 \mathrm{~m}$, gehienez) [7]. GF erako hezegune eraikietan landare urtar mota ugari erabil daitezke; murgilduak, gainerakorrak eta flotatzaileak, besteak beste. Kutsatzaileen eliminazioari dagokionez, egokiak dira metal-aztarnak, materia organikoa eta nitrogenoa ezabatzeko [11].

Hondakin-urak ohantzean zehar soilik dabiltzanean, gainazalaren azpitik, hezegune eraikia gainazal azpiko fluxuko (GAF) erakoa da. Kasu horretan, landaredia legarrez osaturiko ohantzean jasaten da [12], eta ur kutsatua landareen sustrai eta errizomekin dago kontaktuan [7]. Sistema horien sakonera GFena baino apur bat handiagoa izan ohi da, $0,9 \mathrm{~m}$-raino helduz [5]. Fluxuaren norabidearen arabera, mota honetako hezeguneak 
gainazal azpiko fluxu horizontaleko (GAFH) erakoak izango dira, 2. irudia, edo gainazal azpiko fluxu bertikaleko (GAFB) erakoak, 3. irudia.

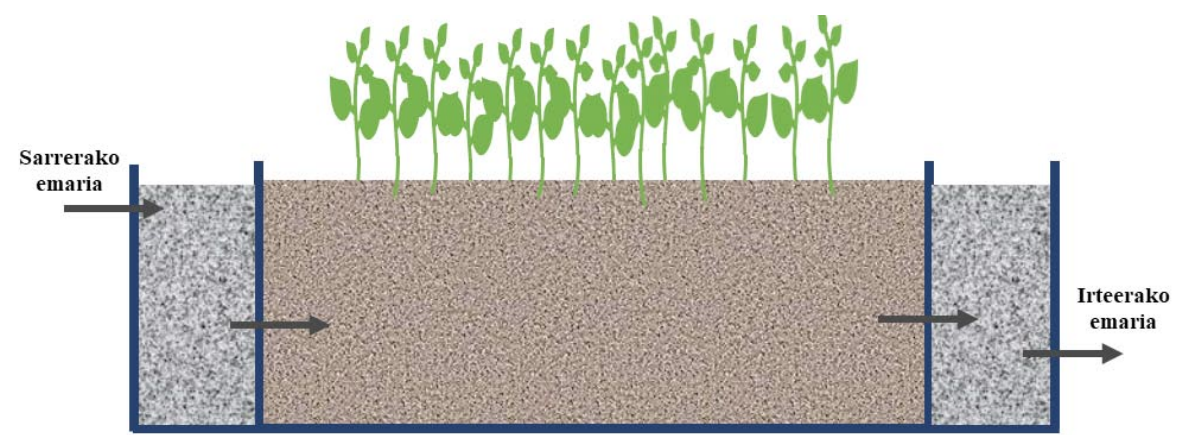

2. irudia. Gainazal azpiko fluxu horizontaleko hezegune eraikiaren eskema.

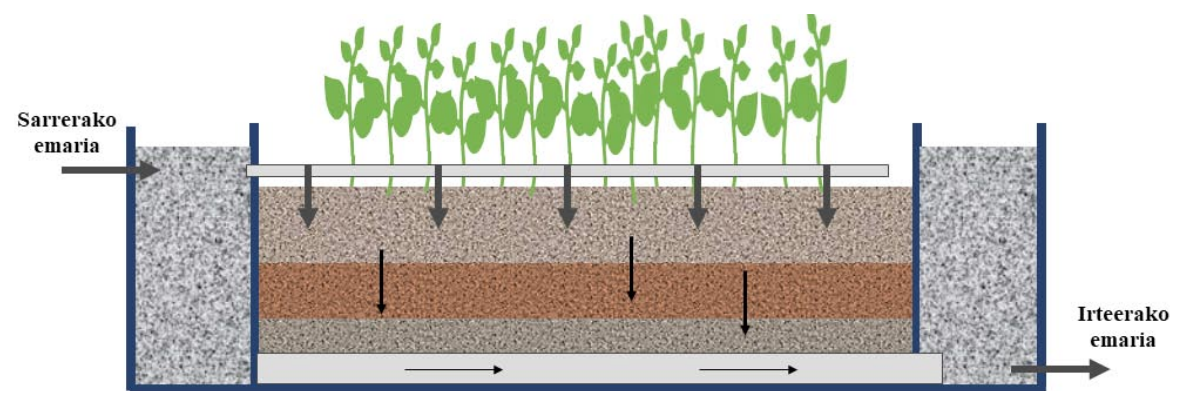

3. irudia. Gainazal azpiko fluxu bertikaleko hezegune eraikiaren eskema.

GAFH Europan gehien erabiltzen den hezegune artifiziala da. Harrerako eta irteerako guneetan ohantzean baino diametro handiagoko legarra erabili ohi da, indargetze gunea deiturikoa osatuz [7]. Aipatzekoa da sistema mota horiek etengabe daudela urez beteta, ura gainazalaren azpitik 0,05 eta $0,1 \mathrm{~m}$ tartean dagoelarik. Garrantzi handikoa da bai hondoaren bai hormen iragazgaiztasuna behar bezala bermatzea, lurpeko uren kutsadura saihesteko. Batzuetan iragazgaiztasuna lurzorua trinkotzearekin lortu arren, gehienetan buztina edo xafla sintetikoak erabiltzen dira helburu horrekin. GAFH hezegune eraikietan, ohantzea funtsezkoa da sistema horren funtzionamendu egokia lortzeko. Izan ere, gune horretan gertazen da esekiduran dauden partikula eta materiaren sedimentazioa, materia organikoaren degradazioa eta mantenugaien asimilazioa [5]. Konfigurazio hori oso egokia da materia organikoa, nitratoak, fosfatoa eta solido esekiak eliminatzeko [11]. 
GAFB hezegune eraikietan, hondakin-urak hezegunearen goiko aldetik hondoraino drainatzen dira, eta ohantzean bertikalki isurtzen dira. Sistema mota horren izaera aerobikoa dela medio, emaitza oso onak lortu ohi dira nitrifikazioan, nitrogenoaren eliminazio-eraginkortasun egokia erdietsiz [11]. GAFB hezeguneetako ohantzeak granulometria ezberdineko geruzez daude osatuta eskuarki, emariak ohantzea ez oso azkar ez oso astiro zeharka ez dezan.

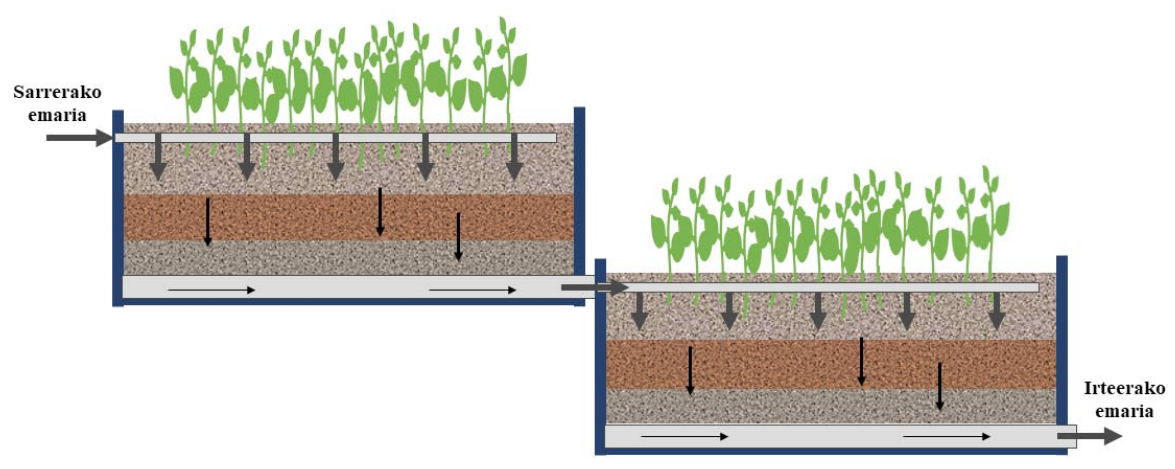

4. irudia. GAFB aireztatua eta GAFH hezeguneak konbinatzen duen sistema hibridoaren eskema.

Askotan, sistemaren eraginkortasuna hobetzeko eta kutsatzaileen eliminazioa bermatzeko, GAFH eta GAFB hezegune artifizialak konbina daitezke [5], 4. irudia. Adibidez, Paingek eta besteek konbinatutako hezegune artifizialen funtzionamendua aztertu zuten [13]. Egile horiek aurretratamendurik gabeko hondakin-ur gordinak elikatu zituzten, eta ohartu ziren lehenengo etaparen goialdean metatzen dela lokatz gehiena, denborarekin iragazketa-prozesuan oso lagungarria bilakatuz. Horri esker, konfigurazio horiek eraikitze-kostu baxuagoak dituzte sistema arrunten aurrean [11]. Horregatik, GAFH eta GAFB hezeguneen abantailak bateratzen dituzten sistema hibridoak gero eta erabiliagoak bihurtzen ari dira. Konfigurazio ugari zehaztu daitezke, hondakin-uren izaeraren arabera, gune aerobikoak edo anaerobikoak lehenetsiz [11]. Gainera, tratamenaren eraginkortasuna handitzeko, aireztatze-sistema ezar daiteke konfigurazio hibridoaren GAFB hezegunean, GAFH hezegunea aireztatu gabe mantenduz, 4. irudia. Aukera hori oso egokia da nitrogeno kantitate altua duten hondakin-urak tratatzeko. Batetik, inguru oxigenatua dela medio, fluxu bertikaleko hezegunean erabatekoa izango da nitrifikazio-prozesua, NH4 nitrito eta nitratoetara biologikoki oxidatuz; eta, bestetik, fluxu horizontaleko hezeguneko gune anaerobikoan, produktu nitrifikatuak nitrogeno-gasera erreduzi daitezke, desnitrifikazio-prozesu anaerobikoari esker [12]. 
GF hezegunearekin alderatuta, GAF erako hezeguneak landa-eremu gutxiago behar izan ohi du [14], tratamendu-ahalmen handiagoa [12]; hau da, azalera-unitateko kutsatzaileen eliminazio-tasa handiagoa lortzen du, eta, horrela, karga organiko handiagoa onartzen du. Gainera, intsektuak agertzeko arriskua murrizten du [5], eta klima hotzetan ur-fluxuaren izoztea saihesten du. Azpimarratzekoa da, paisaiari eta ingurumenari dagokionez, GF hezeguneak GAF erakoak baino erakargarriagoak direla, anfibio edota arrain espezie ugari har baititzakete [7]. Nolanahi ere, hondakin-uren tratamenduaren ikuspuntutik, GAF dira hezeguneak erabilienak mundu mailan, bai GAFHak baita GAFBak ere. 1. taulan laburtu dira bi hezegune eraiki horien abantailak eta desabantailak.

1.taula. GAFH eta GAFB hezegune eraikien abantailak eta desabantailak.

\begin{tabular}{|c|c|c|}
\hline Mota & Abantailak & Desabantailak \\
\hline \multirow{3}{*}{ GAFH } & $\begin{array}{l}\text { Materia organikoaren eta solido ese- } \\
\text { kien eliminazio eraginkorra [11] }\end{array}$ & Landa-eremu handiak behar dira [12] \\
\hline & $\begin{array}{l}\text { Desnitrifikazioaren bidezko nitratoen } \\
\text { eliminazioa, izaera anaerobikoari es- } \\
\text { ker [14] }\end{array}$ & $\begin{array}{l}\text { Hondoaren eta hormen iragazgaizta- } \\
\text { suna ez bada egokia, lurpeko uraren ku- } \\
\text { tsadura gerta daiteke [5] }\end{array}$ \\
\hline & $\begin{array}{l}\text { Azido humikoen sorkuntza N-ren eta } \\
\text { P-ren degradazioa errazteko [12] }\end{array}$ & Amonioaren oxidazio eskasa [12] \\
\hline \multirow{3}{*}{ GAFB } & Landa-eremu baxua behar dute [12] & $\begin{array}{l}\text { Desnitrifikazio-prozesu eskasa eta ni- } \\
\text { tratoak eliminatzeko zailtasunak [14] }\end{array}$ \\
\hline & $\begin{array}{l}\text { Nitrifikazio-prozesu ona, izaera aero- } \\
\text { bikoa dela eta [7] }\end{array}$ & $\mathrm{P}$ eliminazio urria [12] \\
\hline & $\begin{array}{l}\text { Arazketa ona granulometria ezberdi- } \\
\text { neko ohantzeen ondorioz [5]. }\end{array}$ & \\
\hline
\end{tabular}

\section{LANDARETZAREN AUKERAKETA}

Hezegunean landatzen diren espezieen aukeraketa sustraien eta lurperatutako errizomen araberakoa da [7]. Landareak eguzkiaren energiaz baliatzen dira karbono inorganikoa karbono organikoa bihurtzeko, eta atmosferako oxigenoa sustraietaraino garraiatzen dute zurtoinen bidez. Oxigeno horri esker, mikroorganismoek materia organikoa degradatzeko erabiliko duten gune aerobikoa sortzen da. Horrez gain, emariaren abiadura moteltzen dute solido esekiak jalki daitezen, mantenugaiak xurgatzen dituzte [7], eta iragazle gisa jokatzen dute [12]. Aukeratutako landareek kolonizatzaile aktiboak izan behar dute, eta erraz hazi behar dute sistema instalatuko den 
tokiko kliman [5]. Hezeguneetan erabiltzen diren landareak makrofitoak dira, eta lau talde nagusitan sailka daitezke [12]:

- Makrofito emergenteak. Ur gezatan edo murgildutako uretan erabiltzen dira, eta substratuaren gainazaletik $0,5 \mathrm{~m}$ edo gehiagotara dauden uretan haz daitezke. Acorus calamus, Carex rostrata, Phragmites australis edo Scirpus lacustris dira mota honetako makrofitoen adibideak.

- Hostodun makrofito flotatzaileak. 0,5-3 m arteko sakonera duten uretan murgilduta dauden sedimentutan daude sustraituta, eta flotatzen duten zein airean dauden hostoak dauzkate. Adibide bezala, Nymphaea odorada edo Nuphar lutea aipa daitezke.

- Murgildutako makrofitoak. Ehun fotosintetikoa ur azpian dute, eta ondo hazten dira ur oxigenatuetan. Myriophyllum spicatum edo Rhodophyceae dira makrofito hauen adibideak.

- Aske flotatzen duten makrofitoak. Uraren gainazalean flotatzen dute. Lemma miinor, Spirodela polyrhiza edo Eichhornia crassipes, besteak beste.

Europan gehien erabiltzen diren espezieak makrofito emergenteak dira; lezka arrunta, zintabelarra eta ihiak, bereziki [5].

\section{HONDAKIN-UREN KARAKTERIZAZIOA}

Hondakin-uren konposizioa eta ezaugarriak ezberdinak izango dira iturri igorlearen arabera. Halaber, jasotako substantzia kimikoek, banaketa-sareak edota garraioan sor daitekeen degradazioak eragina izan dezakete hondakin-uren konposizioan. Komuneko hondakin-urarekin nahastu gabeko dutxa, bainuontzia, konketa, sukaldea eta garbigailua jatorri duten urei ur grisak deritze [8]. Euren konposizioan ageri diren substantzia ugarienak materia organikoz osatutako konposatu biodegradagarriak eta mantenugaiak dira; besteak beste, nitratoak eta fosforoa (eta horien eratorriak), konposatu organiko xenobiotikoak, eta koliforme fekalak edo Salmonella generoko bakterioak [15]. Oinarrizko konposizio horretaz gain, azken urteetan kutsatzaile emergenteak deituriko farmazia-produktuak, kosmetikoak eta aerosolak agertu izan dira ur grisen konposizioan, baita lehentasunezkoak diren metal astunak ere [16].

Zenbait ikerketa kontuan hartuz, Shaikh-ek eta Ahammed-ek ur grisen kalitateari buruzko berrikusketa sakona argitaratu dute [17]. Kalitatezko ezaugarri kualitatiboak jatorriaren arabera ezberdinak badira ere, azterketa nahikoa da hezegune eraikia bezalako sistemara elikatzen den emariaren kalitateaz jabetzeko. Errenta baxuko herrialdeetan, sukaldetik dator ur grisen kantitate nagusia, \% 28 hain zuzen; hurrengo iturri nagusiak bainugela, 
konketa eta ikuztegia dira, \% 27, \% 21 eta \% 19, hurrenez hurren. Errenta altuko herrialdeetan, berriz, ur gris gehienak bainugelatik datoz, $\% 40$, ikuztegietatik eta sukaldetatik hurrena, $\% 25$ eta $\% 22$, eta konketetatik gutxienekoa, \% 10 [17]. Horrek ur grisen sailkapenean eragiten du, ur gris arinak edo ilunak izan baitaitezke.

2. taula. Ur gris arinen eta ilunen parametro fisikoak [17].

\begin{tabular}{lcc}
\hline \multicolumn{1}{c}{ Parametroa } & Ur gris arinak & Ur gris ilunak \\
\hline Tenperatura, ${ }^{\circ} \mathrm{C}$ & $23,4-29,0$ & $22,4-35,0$ \\
Uhertasuna, NTU & $13-375$ & $34-510$ \\
Solido eseki totalak, $\mathrm{mg} \mathrm{L}^{-1}$ & $7-793$ & $11-4.564$ \\
\hline
\end{tabular}

Lehenengoek dutxatik, bainutik eta konketatik datozen ur grisak barne hartzen dituzte; bigarrenek, aldiz, ikuztegitik, sukaldetik eta harrikoa egitetik datozenak. Berrogeita hamar ikerketa inguru kontuan hartuta, Shaikh-ek eta Ahammed-ek aurresan zuten ur gris arinak errenta baxuko herrialdeen $\%$ 48a eta errenta altuko herrialdeen \% 50a direla [17].

2. taulak ur gris arinen eta ilunen parametro fisiko nagusiak erakusten ditu. Tenperatura ur-horniketa sistemarena baino altuagoa da oro har. Aintzat hartu behar da sukaldean, higiene pertsonalean edo arropa garbitzean ur beroa erabili ohi dela. Tenperatura emariarekin ere erlazionatuta dago [18], balio altuak emari handiekin lotuta daudelako, eta alderantziz. Dena den, jatorri ezberdinen tenperaturak oso antzekoak dira, eta balio altuenak ikuztegitik datozen ur grisetan lortzen dira [17]. Uhertasuna, bestetik, nabariagoa da ur gris ilunetan arinetan baino. Izan ere, sukaldea eta ikuztegia jatorri duten hondakin-urek ur gris arinek baino arretasun-balio altuagoak agertzen dituzte. Joera oso antzekoa ikus daiteke solido esekiekin, askoz ugariagoak baitira ur gris ilunetan. Batetik, arropa garbitzeko erabiltzen diren detergenteek dituzten zeoliten eta zuntzen ondorioz, eta, bestetik, sukaldean barazkiak garbitzean askatzen diren solidoen eraginez. Solido esekien tarteak oso bereizita ditu mugak errenta altuko eta errenta baxuko herrialdeetan eskuarki erabiltzen diren etxetresnak direla medio (plater-ikuzgailua edo garbigailua batetik, eskuzko prozedura bestetik). Izan ere, errenta baxuko herrialdeetan ur eskuragarri gutxiago dagoenez, ura ez dago errenta altuko herrialdeetan bezain diluituta, solido esekien kontzentrazio altuagoak eraginez.

Ur grisen parametro kimiko nagusiak 3. taulan bildu dira; hain zuzen, $\mathrm{pH}-\mathrm{a}$, materia organikoa (Oxigeno Eskari Biologiko, OEB, eta Oxigeno Eskari Kimiko, OEK, bezala neurtuta) eta mantenugaiak (fosforoa eta ni- 
trogenoa). Hondakin-urek $\mathrm{pH}$ ia neutroa izan ohi dute, ikuztegitik datorrenen kasuan izan ezik, detergenteen material alkalinoen ondorioz $\mathrm{pH}$ apur bat altuagoa erakusten baitute. Horren ondorioz, ur gris ilunen alkalinotasuna nabarmenagoa izan daiteke. Espero denez, materia organikoaren kontzentrazioa kuantifikatzeko, OEB eta OEK balioek antzeko joera dute. Sukaldeko eta ikuztegiko urek karga organiko askoz altuagoa daukate konketako eta bainugelako uren aldean. Hortaz, ur gris ilunen batez besteko OEB kontzentrazioa ur gris arinena baino bost aldiz handiagoa da [17]. Lik eta besteek baieztatzen duten legez, materia organikoaren biodegradagarritasuna OEK/OEB erlazioaren bidez neur daiteke, 2,5 baino txikiagoa den kasuetan konposatu organikoak biologikoki erraz degradatzen direla zehaztuz [8]. Shaikhen eta Ahammeden lanetik ondoriozta daiteke ur gris ilunek biodegradagarritasun altua daukatela, sukaldea jatorri duten uren olio eta gantzen kontzentrazio altuak eta detergente biodegradagarriak direla bide. Mantenugaiei dagokienez, ur grisen nitrogeno-kontzentrazioa ur beltzena baino baxuagoa da, urearen eta gorozkien gabeziagatik. Ur grisen artean, nitrogeno gehiago dago ur gris arinetan ilunetan baino, parametro hori bainugelan erabilitako garbiketa-produktuen araberakoa izan baitaiteke. Bestetik, fosforoa agerikoagoa da ur gris ilunetan, detergenteak eta xaboiak konposatu horren kontzentrazio nabaria izaten dutelako [17].

Aipatutako parametro fisiko-kimikoez gain, ur grisen parametro mikrobiologikoak aztergai izan ohi dira giza osasunean duten eraginagatik [19]. Oro har, koliforme totalak eta koliforme fekalak dira adierazle mikrobiologiko erabilienak. Parametro horiek ur grisetan egotearen kausak izan daitezke eskuak garbitzea, sukaldatu gabeko janaria eta haragi gordina edo haurrentzako pixoihalak bezalako produktuak erabiltzea [20]. Espero daitekeenez, bainugela da kutsatzaile biologikoen jatorririk nabarmenena. Aipatu beharra dago ur grisek metal astunen kontzentrazio txikia izan dezaketela, aurretratamenduak era egokian eliminatu ez baditu.

3. taula. Ur gris arin eta ilunen parametro kimikoak [17].

\begin{tabular}{lcc}
\hline \multicolumn{1}{c}{ Parametroa } & Ur gris arinak & Ur gris ilunak \\
\hline $\mathrm{pH}$ & $4,90-8,53$ & $5,00-10,33$ \\
$\mathrm{OEB}, \mathrm{mg} \mathrm{L}^{-1}$ & $20-673$ & $44-3.330$ \\
OEK, $\mathrm{mg} \mathrm{L}^{-1}$ & $23-1.489$ & $58-8.071$ \\
Nitrogeno totala, $\mathrm{mg} \mathrm{L}^{-1}$ & $1,3-148,0$ & $0,5-65,0$ \\
Fosforo totala, $\mathrm{mg} \mathrm{L}^{-1}$ & $0,1-60,0$ & $0,2-187,0$ \\
\hline
\end{tabular}




\section{ARAZKETA-PROZESUAK}

Ur grisen kutsatzaile nagusiak materia organikoa, esekiduran dauden solidoak, nitrogeno amoniakala eta patogenoak dira [7]. Hortaz, konposatu horien aldibereko eliminazioa gauzatzeko zenbait prozesu fisiko, kimiko eta biologikoak gertatzen dira hezegune eraikietan.

Materia organikoaren eliminazioa mikroorganismoen eraginez gauzatzen da batez ere, proportzio txiki bat sedimentazioari zein filtrazioari esker murriztu arren [7]. Behar dituzten mantenugaien arabera, mikroorganismoak autotrofoak edo heterotrofoak izan daitezke. Lehenengoek karbono dioxidoa erabiltzen dute karbono-iturri gisa, eta bigarrenek, aldiz, materia organikoa degradatzen dute mikroorganismo berrien sintesia gauzatzeko. Bestetik, fase likidoan disolbatutako oxigeno kantitateak zehaztuko du ea degradazio aerobikoa edo anaerobikoa gertatzen den. Degradazio aerobikoan mikroorganismo aerobiko kimioheterotrofoek eta kimioautotrofoek hartzen dute parte, konposatu organikoak oxidatuz eta amonioa askatuz eta nitrogeno amoniakala nitrito eta nitratoetara oxidatuz (nitrifikazioa), hurrenez hurren [7]. Materia organikoaren eliminazio-abiadura azkarragoa da mikroorganismo heterotrofoen presentzian, konposatu organikoen degradazioa bakterio horiek gauzatzen baitute gehien bat, erreakzio exotermikoan $\mathrm{CO}_{2}$ eta $\mathrm{H}_{2} \mathrm{O}$ askatuz [21]. Bestetik, disolbaturiko oxigenoaren kontzentrazioa murriztu ahala, degradazio aerobiko bidezko materia organikoaren desagerpena gutxituko da eta degradazio anaerobikoa agertuko da. Azken prozesu hori bakterio heterotrofo anaerobikoek gauzatzen dute; lehenengo etapan, materia organikoa azido eta alkohol bilakatzen da, eta, bigarren urratsean, metano eta karbono dioxido [7].

Esan bezala, solido esekiak ur grisen ohiko kutsatzaileak dira. Dena den, hezegunera elikatu baino lehen, askotan ur grisek aurretratamendu bat (edo gehiago) jasan dute, koipe-tranpak eta sedimentazio-tankeak, besteak beste. Beraz, ur-emaria hezegunera iristen denerako, solido esekien kontzentrazioa baxua izango da. Gainontzeko solido esekien sedimentazioa eta filtrazioa hezegunean bertan gertatzen da, suertatzen diren prozesu fisikoen ondorioz [22]. Landare makrofitoen sustraiek eta ohantze iragazleak uraren abiadura murrizten dute, eta iragazketa zein sedimentazio-prozesuak areagotzen dituzte.

Konposatu nitrogenatuak ugariak dira ekosistema lurtar zein urtarretan, izaki bizidunentzat funtsezkoa den elementu hori oxidazio-egoera eta konposatu ezberdinetan azal baitaiteke: proteinak/aminoazidoak, $\mathrm{NH}_{3}, \mathrm{NH}_{4}{ }^{+}$, $\mathrm{N}_{2}$, nitrogeno oxidoak edota $\mathrm{NO}_{3}^{-}$, besteak beste [23]. Naturan, konposatu nitrogenatuetan aberatsak diren metakin geologikoen, isurketen zein mikroorganismoen deskonposizioaren ondorioz sor daiteke nitrogenoaren metaketa, nitrogenoaren ziklo biogeokimikoa oinarrizko jatorria izanik. Horretan, nitrogenoak egora aldatzen du, finkatze-, nitrifikazio-, asimilazio-, 
amonifikazio- eta desnitrifikazio-prozesuek eratzen duten zikloa osatuz. Atmosfera nitrogeno-gordailu nagusia den arren, izaki bizidunon animalia eta landare bidezko elikadura dela medio, nitrogeno atmosferikoa uretara heltzen da. Uretako bizitzarako beharrezko elementua den arren, jatorri antropologikoa duten konposatu nitrogenatuen kontzentrazioa hazi egin da egungo bizimoduaren eraginez, kutsadura-arazo larriak sorraraziz eta nitrogenoaren ziklo arrunta eraldatuz. Jatorri antropologiko nagusiak erregai fosilak, ongarri nitrogenatuak, kosmetikoak edo paperaren fabrikazioa dira, eta biosferan finkatutako nitrogeno-kontzentrazioa bikoiztea eragin dute [24]. Arrazoi beragatik, tratamendu-sistemetara elikatzen diren ur grisek konposatu horien kontzentrazio gero eta handiagoa dute, eta horrek arazketa-prozesuak moldatzera eta konposatu nitrogenatuen degradazioa ziurtatzen duten teknologiak diseinatzera behartzen ditu. Izan ere, mantenugaien gehiegizko aberastasunak eutrofizazioa eragin dezake, ekosistema urtarrak zein izaki bizidunen osasuna kaltetuz. Amonioak, $\mathrm{NH}_{4}{ }^{+}$, uretako organismoak kaltetu ditzake disolbaturiko oxigenoa agortzearen eraginez. Nitratoek, $\mathrm{NO}_{3}{ }^{-}$, bestetik, gaixotasun kartzinogenikoak edo metahemoglobinemia legezko osasun-arazo larriak eragin ditzakete [25]. Hezegune eraikietan nitrogenoa eliminatzeko prozesuak gauzatzen dira; nitrifikazioa eta desnitrifikazioa dira nagusiak. Sisteman elikatzen den emariak amonio gisa edo amoniora erraz eraldatzen diren konposatu ezegonkor gisa darama eskuarki nitrogenoa. Nitrifikazioan, amonioa nitritoetara eta ondoren nitratoetara biologikoki oxidatzen da, aerobikoki. Prozesu hori amoniakoa eta nitritoa oxidatzeko gaitasuna duten bakterioek egiten dute (AOB eta NOB, hurrenez hurren) $[25,26]$. Prozesua bi etapatan gertatzen da [7]:

$$
\begin{gathered}
\mathrm{NH}_{4}^{+}+3 / 2 \mathrm{O}_{2} \rightarrow \mathrm{NO}_{2}^{-}+2 \mathrm{H}^{+}+\mathrm{H}_{2} \mathrm{O} \\
\mathrm{NO}_{2}^{-}+1 / 2 \mathrm{O}_{2} \rightarrow \mathrm{NO}_{3}^{-}
\end{gathered}
$$

Nitrifikazioan parte hartzen duten bakterio ohikoenak Nitrosomonas, Ek. 1, eta Nitrobacter, Ek. 2, espezieak dira. Hondakin-urek, askotan, nitrifikazioaren inhibitzaileak daramatzate, baina konposatu horiek materia organikoaren digestioan eliminatzen dira. Oxigenoa agortu ahala nitrifikazioa gelditzen da, eta nitratoak nitrogenora erreduzitzen dira, oxido nitriko eta nitrosotik igaroz [7]. Desnitrifikazio izeneko prozesua anaerobikoa da, eta nitrifikazioa baino askoz geldoagoa. Oxigeno gabeziaz gain, materia organikoa egotea da prozesua gertatzeko bigarren baldintza, erreakzioa bakterio heterotrofoek gauzatzen baitute [5].

$$
\mathrm{NO}_{3}{ }^{-} \rightarrow \mathrm{NO}_{2}^{-} \rightarrow \mathrm{NO} \rightarrow \mathrm{N}_{2} \mathrm{O} \rightarrow \mathrm{N}_{2}
$$

Erreakzioan sortzen diren oxido nitriko eta nitrosoa baita nitrogenoa ere produktu gaseosoak dira, baina lehenengo biak iragankorrak izanik, nitrogenoa gas gisa askatzen da gehien bat atmosferara. 
Aipatzekoa da hezegune bertikaletan gune anoxio eskasak daudela, eta ur kutsatuaren erresidentzia denbora laburra dela. Baldintza horiek egokiak dira nitrifikaziorako, eta diseinu egokiarekin nitrifikazio totala lor daiteke. Aldiz, hezegune eraiki horizontaletan, oxigeno-transferentzia baxua denez, gune aerobiko gutxi daude, eta, ondorioz nitrifikazio-prozesua ez da oso eraginkorra; amonioaren eliminazioak ez du \% 30a gainditzen. Alderantzizkoa gertatzen da, ordea, desnitrifikazioarekin. Hezegune bertikaletan gune anoxio eskasak daude, eta nitrifikazioan sortutako nitratoa nitrogeno gas bihurtzeko arazoak eragiten ditu horrek. Hortaz, hezegune bertikalak eta horizontalak seriean koka daitezke, bigarrenean gutxieneko materia organiko kantitatea dagoela ziurtatuz. Horretarako, sistemara elikatutako emariaren zati bat zuzenean bigarren hezegunera desbideratzen da, adibidez [5].

Nitrifikazio-desnitrifikazio prozesuez gain, hezegunean hazten diren landareek amonioa eta nitratoa asimilatzen dituzte, uretatik eliminatuz. Garrantzizkoa da landaredia seneszentzia baino lehenago inaustea; izan ere, horien aireko zatiak hiltzean, nitrogenoa hezegunera itzul daiteke. Nitrogenoa lurrunketaz edota mikrobioen asimilazioz elimina badaiteke ere, ez dauka ardura handirik aurreko prozesuekin alderatuz [5].

4. atalean aipatu den bezala, ur grisek kutsadura mikrobiologikoa ere izan dezakete. Orokorrean, hezegunea baino lehen, aurretratamendurako sistemaren bat proposatzen da elikaduraren kutsadura maila txikiagoa izan dadin. Bertan, partikula solido gehienak sedimentatzeaz gain, bakterio kopuruaren zati bat eliminatzen da. Gero, hezegunearen ohantzean eta prozesu fisiko, kimiko eta biologikoen konbinazioaren eraginez, kutsadura biologikoa ere nabarmen murrizten da. Prozesu fisikoen artean filtrazioa, sedimentazioa edota agregazioa aipa daitezke; kimikoen artean, aldiz, oxidazioa eta adsortzioa, eta, bestetik, landareen sustraiak ere eraginkorrak dira patogenoen kontzentrazioa murrizteko [7].

\section{ONDORIOAK}

Tratatu gabeko urek sortutako osasun- eta ingurumen-arazoak zein gaur egungo ur eskasiaren egoera larria direla eta, hondakin-uren berrerabilpena derrigorrezkoa izatera heldu da. Hezegune naturaletan gertatzen diren arazketa-prozesuak errepikatzen dituzten hezegune eraikiak edota artifizialak gomendatzen dira landa-eremuetan zein komunitate txikietan. Bitan sailka daitezke horiek: gainazaleko fluxuko erakoak eta gainazal azpiko fluxukoak; bigarrenen artean, fluxu horizontal eta bertikalekoak ezberdintzen dira. Sistemaren eraginkortasuna hobetzeko, azken bi hezegune mota horiek konbinatzen dira sistema hibridoak proposatzeko.

Landareen zurtoinen bidez, atmosferako oxigenoa sustraietaraino garraiatzen da, mikroorganismoen bidezko materia organikoaren degrada- 
zioa bideratuz. Horretaz gain sustraiek solido esekien jalkiera eta iragazpena errazten dute, eta mantenugaiak xurgatzen dituzte. Garrantzi handikoa da landareak kolonizatzaile aktiboak izatea, eta, horregatik, tokiko klimara egokitutako makrofitoak aukeratu behar dira. Europan lezka arrunta, zintabelarra eta ihiak erabiltzen dira gehien.

Ur grisak komuneko hondakin-urarekin nahastu gabeko dutxa, bainuontzi, konketa, sukalde eta garbigailuan erabilitako urak dira, euren kutsatzaile nagusia materia organikoa izanik. Horretaz gain, konposatu nitrogenatuak, fosforoa eta koliforme fekalak ere agertzen dira. Zama kutsatzailea txikia denean, ur grisei arinak deritze, eta kontrakoan, aldiz, ilunak.

Materia organikoaren eliminaziorako mekanismo nagusia mikroorganismo autotrofo eta heterotrofo bidezko degradazio aerobiko zein anaerobikoa da. Lehenengoan materia organikoa oxidatzen da, eta nitrogeno amoniakala askatzen, zein nitrito eta nitratoetara oxidatzen den. Hori da mekanismo nagusia fluxu bertikaleko hezegune eraikietan, non oxigenotransferentzia altua baita. Degradazio anaerobikoan, aldiz, konposatu organikoak azido eta alkohol bihurtzen dira, eta, geroxeago, metano eta karbono dioxido. Oxigeno faltan, gainera, nitratoak nitrogenora erreduzitzen dira. Gune anoxioak ugariak dira hezegune horizontaletan.

\section{BIBLIOGRAFIA}

[1] NAN X., LAVRNIĆ S. eta TOSCANO A. 2020. «Potential of constructed wetland treatment systems for agricultural wastewater reuse under the EU framework». Journal of Environmental Managenement, 275, 111219.

[2] GOSLING S.N. eta ARNELL N.W. 2016. «A global assessment of the impact of climate change on water scarcity». Climatic Change, 134, 371-385.

[3] ALMUKTAR S.A.A.A.N., ABED S.N. eta SCHOLZ M. 2018. «Wetlands for wastewater treatment and subsequent recycling of treated effluent: a review». Environmental Science and Pollution Research, 25, 23595-23623.

[4] DIAZ M. 2018. Ecuaciones y cálculos para el tratamiento de aguas. Paraninfo, Madrid.

[5] GARCÍA J. eta CORZO A. 2008. Depuración con humedales construidos. Guía práctica de diseño, construcción y explotación de sistemas de humedales de flujo subsuperficial. Universidad Politécnica de Cataluña, Barcelona.

[6] FAN Y., WU X., SHAO L., HAN M., CHEN B., MENG J., WANG P. eta CHEN G. 2021. «Can constructed wetlands be more land efficient than centralized wastewater treatment systems? A case study based on direct and indirect land use». Science of the Total Environment, 770, 144841.

[7] DELGADILlO O., CAMACHO A., PÉREZ L.F. eta ANDRADE M. 2010. Depuración de aguas residuales por medio de humedales artificiales, Serie 
Técnica. Centro Andino para la Gestión y Uso del Agua, Cochabamba, Bolivia.

[8] LI F., WICHMANN K. eta OTTERPOHL R. 2009. «Review of the technological approaches for grey water treatment and reuses». Science of The Total Environment, 407, 3439-3449.

[9] FERNÁNDEZ J., MIGUEL E. 2004. Manual de fitodepuración. Ayuntamiento de Lorca, Universidad Politécnica de Madrid, Madrid.

[10] THALLA A.K., DEVATHA C.P., ANAGH K. eta SONY E. 2019. «Performance evaluation of horizontal and vertical flow constructed wetlands as tertiary treatment option for secondary effluents». Appl Water Sci, 9, 147.

[11] PARDE D., PATWA A., SHUKLA A., VIJAY R., KILLEDAR D.J. eta KUMAR R. 2021. «A review of constructed wetland on type, treatment and technology of wastewater». Environmental Technology \& Innovation, 21, 101261.

[12] SAEED T. eta SUN G. 2012. «A review on nitrogen and organics removal mechanisms in subsurface flow constructed wetlands: Dependency on environmental parameters, operating conditions and supporting media». Journal of Environmental Management, 112, 429-448.

[13] PAING J., GUILBERT A., GAGNON V. eta CHAZARENC F. 2015. «Effect of climate, wastewater composition, loading rates, system age and design on performances of French vertical flow constructed wetlands: A survey based on 169 full scale systems». Ecological Engineering, Special Issue: 5th International Symposium on Wetland Pollutant Dynamics and Control, 80, 46-52.

[14] BAKHSHOODEH R., ALAVI N., OLDHAM C., SANTOS R.M, BABAEI A.A., VYMAZAL J. eta PAYDARY P. 2020. «Constructed wetlands for landfill leachate treatment: A review». Ecological Engineering, 146, 105725.

[15] OTENG-PEPRAH M., ACHEAMPONG M.A eta DEVRIES N.K 2018. «Greywater characteristics, treatment systems, reuse strategies and user perception-a review». Water Air Soil Pollut, 229, 255.

[16] ERIKSSON E., SRIGIRISETTY S. eta EILERSEN A.M. 2010. «Organic matter and heavy metals in grey-water sludge». Water $S A, 36$.

[17] SHAIKH I.N eta AHAMMED M.M. 2020. "Quantity and quality characteristics of greywater: A review». Journal of Environmental Management, 261.

[18] BIRKS R. eta HILLS S. 2007. «Characterisation of indicator organisms and pathogens in domestic greywater for recycling». Environ Monit Assess, 129, 61-69.

[19] MAIMON A., FRIEDLER E. eta GROSS A. 2014. «Parameters affecting greywater quality and its safety for reuse». Science of The Total Environment, 487, 20-25.

[20] BLANKY M., RODRÍGUEZ-MARTÍNEZ S., HALPERN M. eta FRIEDLER E. 2015. «Legionella pneumophila: From potable water to trea- 
ted greywater; quantification and removal during treatment». Science of The Total Environment, 533, 577-565.

[21] AHMAD FARID M.A, ZAKARIA M.R., HASSAN M.A., MOHD ALI A.A., OTHMAN M.R., IBRAHIM I., SAMSUDIN M.H eta SHIRAI Y. 2019. «A holistic treatment system for palm oil mill effluent by incorporating the anaerobic-aerobic-wetland sequential system and a convective sludge dryer». Chemical Engineering Journal, 369, 165-204.

[22] SCHIERANO M.C., PANIGATTI M.C., MAINE M.A., GRIFFA C.A. eta BOGLIONE R. 2020. «Horizontal subsurface flow constructed wetland for tertiary treatment of dairy wastewater: Removal efficiencies and plant uptake». Journal of Environmental Management, 272, 111094.

[23] CALVACHI G.L.C. eta ORTIZ I.A.S. 2013. «Nitrógeno en aguas residuales: Orígenes, efectos y mecanismos de remoción para preservar el ambiente y la salud pública». Universidad y Salud, 15.

[24] CERVANTES-CARRILLO F., PÉREZ J. eta GÓMEZ J. 2000. «Avances en la eliminación biológica del nitrógeno de las aguas residuales». Revista Latinoamericana de Microbiología, 42, 73-82.

[25] LAI C., GUO Y., CAI Q. eta YANG P. 2020. «Enhanced nitrogen removal by simultaneous nitrification-denitrification and further denitrification (SND-DN) in a moving bed and constructed wetland (MBCW) integrated bioreactor», Chemosfere, 261, 127744.

[26] DEGRÉMONT 1979. Manual técnico del agua. Gráficas Grijelmo, Bilbao. 
